facturer's make is rarely up to standard. The principal reason why the doctor should not dispense is a plain one. The pharmacist is a safeguard to the physician. No matter what mistake the doctor makes the efficient, educated pharmacist will correct it and many a life has been saved on that account.

The lot of the pharmacist is surely not a happy one. He is the servant of the people. He merely lives for them. He strains every nerve to accommodate the doctor as well as the general public, and what does he get for it? The physician allies himself with the manufacturing chemist to enrich him and to help himself, and the dear public wonders why men make such fools out of themselves.

But in spite of the manufacturing pharmacist, or better called manufacturing patent medicine maker, the apothecary shop-keeper will continue to exist and better days are in sight for him. Yours very respectfully, E. v. HermanN.

\section{"Poor Carrasquilla."}

New YoRK, January 31, 1897.

To the Editor:- "A discussion of serum treatment followed, in which poor Carrasquilla suffered. Excepting by his own countrymen, no results were reported from the use of his discovery, and the Germans, the English and others came down in full force to deny not only the usefulness but to argue dangers from its employment. . . . Poor Carrasquilla, to have traveled so far and yet found so little at the end of his journey."-New Orleans Medical and Surgical Journal, December, 1897, Special Correspondence on "The Berlin Leprosy Conference."

When the lion was sick, every beast whom he had wronged in his life came to have a blow at him; and when the ass had for some time contemplated this spectacle, with growing courage he actually went and tried a kick of his own. Such a thing happens frequently among men; but, whoever playe the donkey in such a case let him make quite sure that the lion is past revival.

Poor Carrásquilla! His serum treatment has been coldshouldered in Berlin; he who had gone, his heart so full of hope, returns crestfallen; Dr. Dyer weeps over him, for when he read his paper on antivenomous treatment of leprosy, it was received with bated breath and was generally considered startlingly bold, and Dr. Dyer, thus encouraged (for he is, I suppose, responsible for the utterances of his co-editor) thought that his ideas would revolutionize the treatment of leprosy all over the world. This is interesting. Does not Dr. Dyer think that if anybody should have proposed to cure leprosy by roasting one side of a leper's body, such a proposition would also be listened to with bated breath? Such a treatment would probably be considered also as startlingly bold. Yet, would this checked breathing of a startled conference entitle Dr. Dyer to hope that the treatment of leprosy would be revolutionized by the views he exposed with such tremendous effect. How does he reconcile this hope, proclamed with such a strange flourish of trumpets, with the conclusions arrived at by his adored conference ("long live the Berlin conference!")? Has Dr. Dyer any logical fiber at all?

It seems to me that if Dr. Carrasquilla is to be called poor, he who has at least some intelligible theory to stand upon, Dr. Dyer would deserve the name of a poor beggar, for his pretensions are based upon nothing at all.

$$
\text { A lbert S. Ashmead, M.D. }
$$

\section{Rubaiyat-a Persian Quatrain.}

Chicago, Jan. 15, 1898.

To the Editor:--In your review of the book, the "Rubaiyat of Doc. Sifers," you fail to tell us what Rubaiyat means. Will you kindly supply the defect? Yours very truly,

Answer-We quote the following from a work in the Public Library on Persian literature: "His poetry is wholly composed of independent stanzas, called Rubaiyat, consisting each of four lines of equal, though varied, prosody ; sometimes all rhyming, but of tener the third line a blank. As usual with such Oriental verse, the Rubaiyat follow one another according to alphabetic rhyme-a strange succession of grave and gay. . . At all events each Rubr'iy is a separate poem and, however composed, finds its place in the manuseripts in accordance with its alphabetic arrangements and not its content. The late M. J. Darmesteter describes the Ruba'iy as a poem complete in itself, with its own unity of form and idea, and when wielded by a genuine poet unequaled in force by any other kind of Persian verse, the repetition of the rhymes enveloping and accentuating the silence of the third line, which is generally left blank, producing harmonies and contrasting sounds calculated to give a peculiar relief to the harmonies and contrasts of the idea."

\section{Do Adult Squirrels Castrate Each Other?}

Chicago, Jan. 25, 1897.

To the Editor:-I have read with much interest Dr. Edmund Andrewg' article on "The Oriental Eunuchs," in the Journal, Jan. 22, 1898, wherein speaking of the castration of animals and says anent squirrels: "Naturalists state that the black or gray male squirrels in fighting seek to castrate each other with their teeth, so that many of those taken by hunters are thus mutilated. As they do it only in adult life it does not materially change their general development." Commenting upon this, later, in a letter to the Journal dated Jan. 25, 1898, he quotes the observations of Dr. A. S. Allen.

Being somewhat of squirrel-hunter myself I wish to confirm the report of Dr. Allen. I should say that fully one.half the male squirrels I have noticed were castrated. This is always done in early life, not merely in the nest as described by Dr. Allen, but also after they begin to run. It is always done by the male parent. The young are chased from limb tolimb and tree to tree until exhausted, when the old ones deliberately remove the testes and scrotum clean from the body. The practice is not confined to the gray squirrel. I have noticed it more frequently among the large fox squirrels found in Illinois.

I believe such an operation to be impossible among adult animals engaged in battle. The operation is, in most cases, done so neatly with their sharp teeth that no vestige of tissue remains. At first $I$ took it for granted that they were all females, although I could not account for their large size. The large size of these animals, the perfectly healed wounds and the seeming impossibility of performing such a neat operation in a fit of anger, as suggested by naturalists, would forbid the conclusion that such operations are ever performed in adult life. The castrated are much fatter than the perfect males.

The only cause which I could assign for this methodical operation is that of jealousy, which is shared by the farmer who lives in the vicinity.

The practice may be taken in its mental origin to the sexual mental state underlying the driving forth of young males by the old ones among social animals.

Eugene S. Talbot, M.D.

\section{PUBLIC HEALTH.}

The "Caffery Bill" as reported to the Senate January 19, by Senator Vest.-That "An Act granting additional quarantine powers and imposing additional duties upon the Marine-Hospital Service," approved February flfteenth, eighteen hundred and ninety-three, be amended by striking out the following words in section one: "And with such rules and regulations of State and municipal health authorities as may be made in pursuance of or consistent with this Act," and striking out section three and inserting the following in the place of said section : 